\title{
134. Spezielle Techniken der Shunt-Chirurgie
}

\author{
A. J. Coburg, G. Tidow, E. Wagner, H.-J. Meyer und Ch. Brölsch \\ Klinik für Abdominal- und Transplantationschirurgie (Leiter; Prof. Dr. R. Pichlmayr), \\ Department Chirurgie, Medizinische Hochschule Hannover
}

\section{Special Techniques in Arteriovenous Fistulas for Hemodialysis}

Summary. At Hannover Medical School, 1000 shunt procedures have been performed, including anastomosis with the basilic vein ( 18 cases), interposition of the saphenous vein ( 23 cases) or of a bovine xenograft (21 cases), used straight or as a loop. Lately the authors have used xenografts instead of the autologous saphenous vein, thereby easing anesthesia and the actual operation. Some special techniques are used: (1) pulling through of interposed vessels is facilitated by using rubber tubes that are subcutaneously channeled on a rod; (2) in repeated thrombosis of a shunt, local heparinization is instituted with $5-10000 \mathrm{U} / 24 \mathrm{~h}$ over 3-5 days via a small Intracath, the tip of which is brought up $15 \mathrm{~cm}$ into the arterial shunt vessel. In this way, 12 of 18 shunts were kept open and saved from definite thrombosis; (3) in cases with lesions such as stenosis, aneurysm or rupture of a xenograft after puncture wound infection ( 2 cases), interposition of a short segment xenograft helped to save the shunts.

Key words: Shunt, arteriovenous - Heparinisation, local - Graft, heterologous.

Zusammenfassung. An der Medizinischen Hochschule Hannover wurden über 1000 Shunt-Operationen durchgeführt, darunter 18mal mit der Basilica, 23 Fälle mit Saphena-Interposition, 21 mit heterologem Gefäßersatz (Kälberarterien). Nach den Ergebnissen mit Letztgenanntem wird das Saphenainterponat kaum noch benötigt, der Eingriff vereinfacht sich. Spezielle Techniken: (1) Für den subcutanen Durchzug von Interponaten werden Drainageschläuche mit Spieß verwandt. (2) Bei rezidivierenden Thrombosen wird eine lokale Heparinisierung durchgeführt mit 5-10000 E/24 h über 3-5 Tage mittels eines dünnen Intracaths, der $15 \mathrm{~cm}$ in den zuführenden arteriellen Schenkel eingebracht wird. 12 von 18 Shunts bzw. Interponate konnten offengehalten und vor der definitiven Thrombose bewahrt werden. (3) Zur Úberbrückung kurzstreckiger Läsionen wie Stenosen, Aneurysmen oder Ruptur eines Xenografts unter infizierten Wunden (2 Fälle!) wurden kurze Segmente von heterologem Gefäßersatz interponiert.

Schlïsselwörter: Arteriovenöse Shunts - Lokale Heparinisierung - Heterologer Gefäßersatz. 